\title{
FACTORS INFLUENCING THE CONCENTRATION GRADIENT OF PROTEIN IN CEREBROSPINAL FLUID ${ }^{1,2}$
}

\author{
By ROBERT A. FISHMAN, JOSEPH RANSOHOFF, AND ELLIOTT F. OSSERMAN \\ WITH THE TECH NICAL ASSISTANCE OF DOLORES P. LAWLOR
}
(From the Departments of Neurology, Neurosurgery and Medicine, College of Physicians and Surgeons, Columbia University and the Neurological Institute, Presbyterian Hospital, and The Francis Delafield Hospital, New York, N. Y.)

(Submitted for publication February 6, 1958; accepted June 19, 1958)

The concentration of protein in the cerebrospinal fluid (CSF) is about 0.5 per cent that of plasma. This difference in concentration is generally considered (1) to be dependent upon the blood-CSF barrier. The normal concentration gradient of protein from a low level in the ventricles, 6 to $15 \mathrm{mg}$. per cent, to an intermediate level in the cisterna magna, 15 to $25 \mathrm{mg}$. per cent, to the highest level in the lumbar sac, 20 to $45 \mathrm{mg}$. per cent (2), has not been satisfactorily explained. To study the nature of this gradient, two groups of experiments were performed, determining: 1) the exchange of radioiodinated serum albumin (RISA ${ }^{\circledR}$ ) between the plasma and the various levels in the CSF, and 2) the relative concentration of the albumin, globulin and "prealbumin" constituents at these levels, employing zone electrophoretic analysis.

In previous investigations in the dog (3), it has been shown that the plasma albumin exchanges rapidly with the protein in the CSF. Following intravenous injection, RISA ${ }^{\circledR}$ appeared in the cisternal fluid within 20 minutes, reached a maximum at about 20 hours, and subsequently disappeared at a slower rate than in the plasma. In the present study, RISA was administered intravenously to infants with communicating hydrocephalus to determine if differences in the rates of RISA ${ }^{\circledR}$ appearance exist at different sites along the neuraxis. The demonstration of such rate differences could then be interpreted to indicate nonuniformity of the blood-CSF barrier to protein at these different levels. Similarly, the concentration of albumin in CSF would be expected to be

1 This work was aided in part by a grant from the National Multiple Sclerosis Society.

2 This paper was presented in part at the Annual Meeting of the American Neurological Association, June, 1955, Chicago, Ill. greatest in the region of maximal permeability of the barrier.

\section{METHODS}

For the isotopic studies, 12 infants, ranging in age from one to nine months, were studied. In all cases the diagnosis of communicating hydrocephalus was established by ventriculography and dye test or pneumoencephalography. Lugol's solution was administered 24 hours before the study and continued 10 days in order to block thyroidal uptake of the isotopic iodine. Three hundred to 500 microcuries of radioiodinated serum albumin $^{3}$ was administered intravenously, four to nine hours prior to combined ventricular, cisternal and lumbar puncture. Eight milliliters of CSF was removed from each of these sites, within a five minute interval. In each case the ventricular fluid was obtained first and the lumbar fluid last. Samples containing more than 100 red blood cells or 10 white blood cells per cubic milliliter were considered contaminated with blood proteins and were discarded. The CSF samples were dialyzed against 0.85 per cent $\mathrm{NaCl}$ for 24 hours to remove unbound radioiodine. Radioactivity was measured in duplicate samples with a well-type scintillation counter. The total protein of each sample was determined turbidimetrically using 5 per cent sulfosalicylic acid (4). Specific activity was determined as counts per minute per milligram of total protein, rather than per milligram of albumin, because limitation of sample size precluded separation of the albumin and globulin fractions.

For the electrophoretic analysis of ventricular and lumbar fluids, two groups of patients were studied: infants with communicating hydrocephalus, and children and adults with brain tumors in whom blood-free CSF samples could be obtained. The ages and diagnoses are noted in Table II. Ten to 15 milliliter samples of ventricular and then lumbar fluid were obtained from the patients within a 15 minute period. Samples which were contaminated with blood as defined above were discarded. All samples of cerebrospinal fluid were concentrated by dialysis in cellophane tubing, ${ }^{4}$ against a 25 per cent solution of polyvinylpyrollidone. ${ }^{5}$ Osmodialysis was carried

3 Abbott Laboratories, North Chicago, Ill.

4 Visking Corporation, Chicago, Ill.

5 PVP Type NP $K_{80}$, General Aniline and Film Corporation, New York, N. Y. 
TABLE I

Summary of the data obtained in five infants with communicating hydrocephalus with regard to the total protein content and specific activity at the various levels in the cerebrospinal fluid (CSF), following radioiodinated serum albumin (RISA $®)$ administration

\begin{tabular}{|c|c|c|c|c|c|c|}
\hline \multirow[b]{2}{*}{ Case } & \multicolumn{3}{|c|}{ Protein content (mg. \%) } & \multicolumn{3}{|c|}{ Specific activity (cpm/mg.) } \\
\hline & $\begin{array}{l}\text { Vent. } \\
\text { fluid }\end{array}$ & $\begin{array}{l}\text { Cisternal } \\
\text { fluid }\end{array}$ & Lumbar & $\begin{array}{l}\text { Vent. } \\
\text { fluid }\end{array}$ & $\begin{array}{l}\text { Cisternal } \\
\text { fluid }\end{array}$ & $\underset{\text { fumbar }}{\text { Lumbar }}$ \\
\hline $\begin{array}{l}1 \\
2 \\
3 \\
4 \\
5\end{array}$ & $\begin{array}{r}11 \\
29 \\
52 \\
16 \\
105\end{array}$ & $\begin{array}{l}13 \\
37 \\
55\end{array}$ & $\begin{array}{r}19 \\
45 \\
62 \\
34 \\
126\end{array}$ & $\begin{array}{r}107 \\
0 \\
637 \\
78 \\
67\end{array}$ & $\begin{array}{l}147 \\
735 \\
829\end{array}$ & $\begin{array}{r}289 \\
914 \\
1,600 \\
783 \\
301\end{array}$ \\
\hline
\end{tabular}

out at $5.0^{\circ} \mathrm{C}$. for 16 hours, resulting in a twenty- to thirtyfold concentration. A final protein concentration in excess of 1 gram per cent is suitable for filter paper electrophoretic analysis. Filter paper electrophoresis was performed under the standard conditions employed for the analysis of serum proteins, viz.: barbital buffer, $\mathrm{pH}$ 8.6; ionic concentration, $\mu=0.075$; voltage gradient, $2.5 \mathrm{~V} / \mathrm{cm}$.; duration, 16 hours. Proteins were stained with bromphenol blue dye, and the relative concentrations of globulin, albumin and the prealbumin $\mathrm{X}$ fractions were determined by photometric densitometry of the stained electrophoretic patterns. ${ }^{6}$ Satisfactory separation of the alpha, beta and gamma subfractions of globulin was not obtained.

\section{RESULTS}

In the isotopic studies, of the 12 infants studied, 7 cases were discarded because of the complication of bloody taps, as defined above. The data on

${ }^{6}$ Spinco, Model R, filter paper electrophoresis system, Beckman Instruments, Spinco Division, Palo Alto, Calif.

TABLE II

Summary of the data obtained in nine patients with regard to the electrophoretic analysis of ventricular and lumbar cerebrospinal fluid (CSF)

\begin{tabular}{|c|c|c|c|c|c|c|c|c|c|c|c|c|c|c|c|c|c|c|}
\hline \multirow[b]{2}{*}{ Patient } & \multirow[b]{2}{*}{ Age } & \multirow[b]{2}{*}{ Diagnosis } & \multicolumn{2}{|c|}{$\begin{array}{c}\text { Total } \\
\text { protein }\end{array}$} & \multicolumn{2}{|c|}{$\mathrm{X}$ fraction } & \multicolumn{2}{|c|}{ Albumin } & \multicolumn{2}{|c|}{ Globulin } & \multicolumn{2}{|c|}{$\mathrm{X}$ fraction } & \multicolumn{2}{|c|}{ Albumin } & \multicolumn{2}{|c|}{ Globulin } & \multicolumn{2}{|c|}{$\mathbf{A} / \mathrm{G}$} \\
\hline & & & V.* & L.† & V. & L. & V. & L. & V. & L. & V. & L. & v. & L. & V. & L. & V. & L. \\
\hline & & & \multicolumn{2}{|c|}{ mg. \% } & \multicolumn{2}{|c|}{$\%$} & \multicolumn{2}{|c|}{$\%$} & \multicolumn{2}{|c|}{$\%$} & \multicolumn{2}{|c|}{$m g . \%$} & \multicolumn{2}{|c|}{$m g . \%$} & \multicolumn{2}{|c|}{ mg. \% } & & \\
\hline 1 & 4 mos. & $\begin{array}{l}\text { Communicating } \\
\text { hydrocephalus }\end{array}$ & 13 & 22 & 3 & 3 & 30 & 45 & 67 & 52 & 0.4 & 0.7 & 3.9 & 9.9 & 8.7 & 11.4 & 0.45 & 0.86 \\
\hline 2 & $3 \frac{1}{2}$ yrs. & $\begin{array}{l}\text { Communicating } \\
\text { hydrocephalus }\end{array}$ & 36 & 36 & 7 & 3 & 55 & 76 & 38 & 21 & 2.5 & 1.1 & 19.8 & 27.4 & 13.6 & 7.5 & 1.44 & 3.61 \\
\hline 3 & 11 yrs. & $\begin{array}{l}\text { Cerebellar } \\
\text { astrocytoma }\end{array}$ & 10 & 21 & 11 & 1 & 46 & 58 & 43 & 41 & 1.1 & 0.2 & 4.6 & 12.2 & 4.3 & 8.6 & 1.07 & 1.41 \\
\hline 4 & 8 yrs. & $\begin{array}{l}\text { Cerebellar } \\
\text { astrocytoma }\end{array}$ & 9 & 33 & 3 & 2 & 28 & 65 & 69 & 33 & 0.3 & 0.7 & 2.5 & 21.4 & 6.2 & 11.0 & 0.41 & 1.97 \\
\hline 5 & 63 yrs. & $\begin{array}{l}\text { Cerebellar } \\
\text { cyst }\end{array}$ & 16 & 38 & 4 & 1 & 46 & 54 & 50 & 45 & 0.6 & 0.4 & 7.4 & 10.5 & 8.0 & 17.1 & 0.92 & 1.20 \\
\hline 6 & 7 mos. & $\begin{array}{l}\text { 3rd ventricle } \\
\text { tumor }\end{array}$ & 18 & 65 & 5 & 1 & 26 & 48 & 69 & 51 & 0.9 & 0.6 & 4.7 & 31.2 & 12.4 & 33.2 & 0.38 & 0.94 \\
\hline 7 & 9 yrs. & $\begin{array}{l}\text { Cranio- } \\
\text { pharyngioma }\end{array}$ & 20 & 56 & 10 & 4 & 45 & 58 & 45 & 38 & 2.0 & 2.2 & 9.0 & 32.5 & 9.0 & 21.3 & 1.00 & 1.52 \\
\hline 8 & 61 yrs. & $\begin{array}{l}\text { Cerebellar } \\
\text { tumor, } \\
\text { metastatic }\end{array}$ & 15 & 92 & 10 & $\mathbf{0}$ & 42 & 69 & 48 & 31 & 1.5 & 0 & 6.3 & 63.5 & 7.2 & 28.5 & 0.91 & 2.22 \\
\hline 9 & 11 yrs. & $\begin{array}{l}\text { Medullo- } \\
\text { blastoma }\end{array}$ & 16 & 120 & 12 & 3 & 24 & 83 & 64 & 14 & 1.9 & 3.6 & 3.8 & 99.6 & 10.2 & 16.8 & 0.37 & 5.93 \\
\hline
\end{tabular}

* Ventricular.

† Lumbar. 
the acceptable 5 cases are summaried in Table I. As seen in this table, in each case the expected increasing concentration of protein from the ventricle to the lumbar sac was observed. This was true in Cases 1 and 4 with normal protein concentrations, as well as in Cases 2, 3 and 5 which displayed abnormally high concentrations.

The specific activity in all five cases was greatest in the lumbar fluid. In the three cases in which cisternal taps were done, the specific activity in the cisternal fluid was intermediate between that of the ventricular and lumbar fluids. In Case 2, despite significant levels of activity in the lumbar fluid, no activity could be detected in the ventricular fluid. In all instances, the specific activity in the ventricular fluid was lower than that measured in fluid obtained from the cistern or lumbar regions.

The total protein values and the relative concentrations of the three major fractions are presented in Table II. Figure 1 shows representative electrophoretic patterns of the ventricular and lumbar fluids obtained in Case 7.

The concentration of the prealbumin $\mathrm{X}$ fraction in the ventricular CSF exceeded that in the lumbar fluid in all cases except Case 1, in which the concentrations were equal. The average concentration of fraction $\mathrm{X}$ was 7.2 per cent of the total protein in ventricular fluid and 2.0 per cent in lumbar fluid. The amount of fraction $\mathrm{X}$ in ventricular and lumbar fluid, however, was variable; in five cases (Nos. 2, 3, 5, 6 and 8) the amount in the ventricular fluid was greater; in four cases (Nos. 1, 4, 7 and 9) the lumbar content was greater. There was no apparent correlation between fraction $\mathrm{X}$ content and total protein, albumin, or globulin content. The absence of fraction $\mathrm{X}$ from the lumbar fluid of Case 8 is not explained.
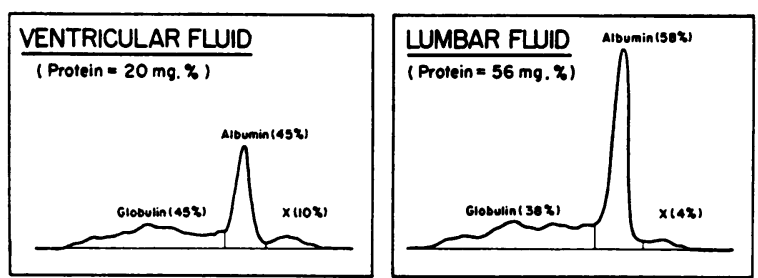

Fig. 1. Represéntative Electrophoretic Patterns of the Ventricular and Lumbar Fluids Obtained IN CASE 7
The lumbar fluid in all cases contained relatively more albumin than globulin; the ventricular fluids showed just the reverse composition. The average concentration of albumin in lumbar fluid was 62 per cent; of globulin, 36 per cent. The average concentration of albumin in ventricular fluid was 38 per cent; of globulin, 54 per cent. The quantity of albumin was variable but in each case the lumbar content exceeded the ventricular content. The quantity of globulin in lumbar CSF was also increased in eight of the nine cases (exception, Case 2), but the albumin increment was much greater as noted by the $A / G$ ratio which was always greater in the lumbar CSF. The average $A / G$ ratio in ventricular fluid was 0.77 ; in lumbar fluid, 2.23. In two cases with brain tumor, Cases 8 and 9, and a marked increase in the lumbar total protein, there was marked elevation of the lumbar $A / G$ ratio.

\section{DISCUSSION}

The existence of the blood-CSF barrier to protein is clearly evidenced by the marked difference in protein concentration in these fluid compartments. The albumin and globulin of CSF are considered to originate from the plasma except in some disease states, notably neurosyphilis and multiple sclerosis, where the abnormally elevated CSF gamma globulin may be formed within the central nervous system (5). The abnormal plasma globulin, characteristic of multiple myeloma, has also been found in the CSF $(5,6)$. The gradient in protein concentration from the ventricle to the lumbar sac, in normal and many pathological states, has been well described (2). In a patient with a complete block in the spinal subarachnoid space, Sweet and co-workers (7), employing intravenously injected RISA ${ }^{\circledR}$, have presented evidence that the increased concentration of protein below the block is secondary to a defect in absorption or removal of protein. The present studies have been devised to explain the protein gradient in cases without obstructive lesions in the spinal subarachnoid space.

The previously demonstrated (3) equilibration of RISA ${ }^{(1)}$ between plasma and CSF clearly established the dynamic exchange of albumin between these fluid compartments. The present studies have shown that albumin permeates the 
blood-CSF barrier at multiple sites along the neuraxis, in agreement with the findings of Sweet and co-workers (7). The choroid plexus does not appear to be essential for the entry of albumin into the CSF. These data supplement the previously reported exchange of sodium (7), chloride (7), potassium (7), glucose (8), urea (9) and water (10) at multiple sites along the neuraxis. It must be recognized, however, as Davson (1) and Bering (10) have emphasized, that the exchange of substances between the plasma and CSF must be distinguished from net changes in volume.

The amount of protein in CSF and the rates of exchange of protein between the blood and the several levels of the CSF are probably dependent upon several independently operating permeability factors. Likewise, the barrier at each of these levels must be considered to be composed of a number of structures, including the capillary endothelium, pia-glial membrane, ependyma, choroid plexus and the arachnoid membranes, each of which may possess different permeability characteristics. The protein concentration gradient from the ventricle to the lumbar sac, in normal and many pathological states, is also dependent upon several different factors including the nature of the barrier at the various levels, mixing within the ventricles and subarachnoid space, and the removal mechanisms that may be operative in the subarachnoid space and at the arachnoid villi. It is difficult to determine the role of each of these factors in the maintenance of the concentration gradient. However, in the present studies, the specific activity was greatest in the lumbar fluid of each patient, the site of greatest protein concentration. We conclude that the concentration gradient of protein must be in part dependent upon the relatively increased permeability of the blood-CSF barrier to albumin in the region of the spinal subarachnoid space. The electrophoretic data support this conclusion in that the albumin content and the $A / G$ ratio were greater in the lumbar CSF than in the ventricular fluid. If a delay in protein removal in the lumbar region was responsible for the higher protein concentration, the globulin concentration would be expected to be greater and the $A / G$ ratio relatively reduced in this region.

In evaluating the appearance of RISA ${ }^{\infty}$ in the $\mathrm{CSF}$ as an indication of differences in permeability along the neuraxis, the surface-volume relationships at the three levels must be considered. In adults the ratio of surface to volume is considered to be greatest in the cisternal region accounting for the more rapid exchange of $\mathrm{D}_{2} \mathrm{O}$ in this region than in the ventricular or lumbar region (10). There are no data which quantitatively establish the dimensions of the surface-volume ratios at various levels in the CSF pathways in either normal or pathological states. However, the anatomical relationships of the cisterna magna are such that the surface-volume ratio in this area may be assumed to greatly exceed that ratio in the ventricles or lumbar region. In hydrocephalus, the enlarged ventricular system would tend greatly to depress the rate of entry into the ventricles, but: the anatomical relationships in the cisternal and lumbar regions would be relatively unchanged and' expected to be such that the surface-volume ratio. would remain greater in the cisterna magna than in the spinal subarachnoid space. Thus if permeability to albumin were the same in all regions the specific activity would be greatest in the cisterna magna. The demonstration of the consistently greatest specific activity in the spinal region, the site of greatest protein concentration, strongly suggests that the relatively increased protein concentration in lumbar fluid is in part dependent upon the relatively increased permeability characteristics of the membranes comprising the "barrier" in that region. The nature of these experiments has precluded the study of a normal population. However, the radioisotopic and electrophoretic data suggest this generalization: The occurrence of an increasing concentration gradient of protein along the neuraxis, in the absence of an obstruction in the CSF pathways, is in part dependent upon increased permeability of the membranes adjacent to the site of increased protein concentration.

In the isotope studies the specific activity of each sample was calculated as counts per milligram of total protein rather than as counts per milligram of albumin. Because of the limitation of sample size, albumin globulin fractionation could not be performed. It is notable, however, that recalculation of the specific activity data using several different assumed albumin concentrations, does not modify the conclusion that the tracer most rapidly enters the lumbar CSF. Forexample, assuming the albumin concentration to. 
be at least twice as great in the lumbar fluid as in the ventricular fluid does not alter this interpretation.

Those patients with brain tumor and an abnormally elevated lumbar protein had a very marked increase in albumin in the lumbar CSF. There is an increase in the permeability to albumin in the region of brain tumors (11) and this results in an elevated protein throughout the subarachnoid space.

The increasing concentration gradient of protein in the CSF along the neuraxis has, in the past, been attributed to the differential absorption of water in the lumbar subarachnoid space (12). The demonstration by Bering (10) of the very rapid exchange of water between plasma and CSF negates this possibility. The half-times for the exchange of $\mathrm{D}_{2} \mathrm{O}$ in seven normal infants and adults were 1.5 to 6 minutes in cisternal fluid, 2 to 37 minutes in the ventricles, and 7 to 38 minutes in the lumbar region.

So-called "stagnation" (2) in the lumbar region has also been set forth as a possible explanation for the relatively increased protein content. The use of a closed system of recording CSF pressure with a strain-gage manometer has revealed the normal arterial pulse pressure in the lumbar CSF to equal $29 \mathrm{~mm}$. saline (13); the ordinary spinal water manometer obscures this finding. A pulse pressure of this magnitude in the lumbar region makes the concept of "stagnation" or poor mixing most unlikely in the absence of a spinal subarachnoid block. The effect of gravity in maintaining the protein concentration gradient has also been suggested as a possible mechanism. The presence of the concentration gradient in infants that are supine is strongly against such a possibility.

Kabat, Moore and Landow (5), in their electrophoretic studies of the CSF proteins, were the first to describe a component with an electrophoretic mobility greater than that of albumin. Subsequent studies by a variety of investigators (1418), employing several different techniques of concentration of CSF, have confirmed the presence of this fraction. These investigators have variously designated this fraction as fraction $\mathrm{X}(5$, $15,16)$, vorfraktion (17), and prealbumin (18). It has been generally considered that this prealbumin fraction is absent from the plasma $(14,15$, 19) although Pieper (20) has described the ap- pearance of a comparable constituent in plasma following excessive dilution. Employing immunoelectrophoretic analytical techniques, Gavrilesco, Courcon, Hillion, Uriel, Lewin and Graber (21) and Schultze, Schönenberger and Schwick (22) have also noted the presence of a fast migrating fraction in serum. These workers consider this serum fraction to be identical with the prealbumin fraction of CSF. Uzman and Bering (16) and Schultze and co-workers (22) have attempted to characterize this fraction in CSF chemically and physically. The results of these two studies differ on several points including the amino acid composition, ultracentrifugal sedimentation constants and electrophoretic mobility values. Since these two groups of investigators have employed different isolation techniques, part of the disagreement in their results may be ascribed to these methodological differences.

In the present study, it has been found that the concentration of the prealbumin fraction in the ventricular CSF significantly exceeded the concentration of this component in the lumbar CSF. It should be stressed that this concentration differential is in the opposite direction to the concentration distribution of albumin. Steger (23) and Bauer (24) have noted a similar concentration distribution of this fraction. There are no known correlations between $\mathrm{X}$ fraction content in CSF and pathological processes in the nervous system (25).

At present, the site of origin of fraction $\mathrm{X}$ in CSF remains obscure. A recent study by Robertson (26) of the soluble proteins of brain, employing an electrophoretic analytical technique, has noted a fraction with a mobility more rapid than that of albumin in brain tissue. Obviously, it is impossible to equate this soluble brain protein with the prealbumin fraction of CSF without more specific physicochemical characterization. The finding of the greater concentration of this fraction in ventricular CSF, however, does suggest the possibility that this fraction may be derived from brain tissue.

\section{SUM M ARY}

1. Radioiodinated serum albumin was administered intravenously to infants with communicating hydrocephalus. Four to nine hours later, samples of ventricular, cisternal and lumbar cerebrospinal 
fluid were obtained within a five minute period. The specific activity was greatest in lumbar fluid, intermediate in cisternal fluid, and least in ventricular fluid.

2. Samples of ventricular and lumbar cerebrospinal fluid were obtained from infants with communicating hydrocephalus and from children and adults with brain tumors. The relative concentrations of the albumin, globulin and prealbumin (X fraction) constituents in these fluids were determined by zone electrophoretic analysis. The lumbar fluid in all cases contained relatively more albumin than globulin as compared with the ventricular fluid. The ventricular fluid contained more prealbumin ( $\mathrm{X}$ fraction) than the lumbar fluid.

3. These data suggest that the increasing concentration of protein from the ventricle to the lumbar region is a manifestation of greater permeability of the blood-cerebrospinal fluid barrier to proteins in the lumbar region.

\section{REFERENCES}

1. Davson, H. Physiology of the Ocular and Cerebrospinal Fluids. Boston, Little, Brown \& Co., 1956.

2. Merritt, H. H., and Fremont-Smith, F. The Cerebrospinal Fluid. Philadelphia, W. B. Saunders Co., 1938.

3. Fishman, R. A. Exchange of albumin between plasma and cerebrospinal fluid. Amer. J. Physiol. 1953, $175,96$.

4. Denis, W., and Ayer, J. B. A method for the quantitative determination of protein in cerebrospinal fluid. Arch. intern. Med. 1920, 26, 436.

5. Kabat, E. A., Moore, D. H., and Landow, H. An electrophoretic study of the protein components in cerebrospinal fluid and their relationship to the serum proteins. J. clin. Invest. 1942, 21, 571.

6. Wallenius, G. Electrophoretic patterns of cerebrospinal fluid and serum compared in normal and pathological conditions. Acta Soc. Med. upsalien. 1952, 57, 138.

7. Sweet, W. H., Brownell, G. L., Scholl, J. A., Bowsher, D. R., Benda, P., and Stickley, E. E. The formation, flow and absorption of cerebrospinal fluid; newer concepts based on studies with isotopes in Neurology and Psychiatry in Childhood. Baltimore, Williams and Wilkins Co., 1954, vol. 34, p. 101.

8. Riser, and Mériel, P. Le mécanisme de la glycorachie. Presse méd. 1927, 35, 1457.

9. Cestan, LaBorde, and Riser. La perméabilité méningée n'est qu'un des modes de la perméabilité vasculaire. Presse méd. 1925, 33, 1330.
10. Bering, E. A., Jr. Water exchange of central nervous system and cerebrospinal fluid. J. Neurosurg. 1952, 9, 275.

11. Chou, S. N., Aust, J. B., Moore, G. E., and Peyton, W. T. Radioactive iodinated human serum albumin as tracer agent for diagnosing and localizing intracranial lesions. Proc. Soc. exp. Biol. (N. Y.) 1951, 77, 193.

12. Lups, S., and Haan, A. The Cerebrospinal Fluid. Amsterdam and New York, Elsevier Publishing Co., 1954.

13. Bering, E. A., Jr. Choroid plexus and arterial pulsaation of cerebrospinal fluid. Arch. Neurol. Psychiat. (Chicago) 1955, 73, 165.

14. Lemmen, L. J., Newman, N. A., and DeJong, R. N. Study of cerebrospinal fluid proteins with paper electrophoresis. Part I. A review of literature. Univ. Mich. med. Bull. 1957, $23,3$.

15. Fisk, A. A., Chanutin, A., and Klingman, W. O. Observations on a rapidly migrating electrophoretic component of cerebrospinal fluid. Proc. Soc. exp. Biol. (N. Y.) 1951, 78, 1.

16. Uzman, L. L., and Bering, E. A., Jr. The chemical nature of fractions $X$ and $X_{1}$ of human cerebrospinal fluid. Arch. Biochem. 1956, 60, 257.

17. Bücher, T., Matzelt, D., and Pette, D. Papier-elektrophorese von Liquor cerebrospinalis. Klin. Wschr. 1952, 30, 325.

18. Esser, V. Die elektrophoretische Untersuchung des. Liquoreiweisskörper und ihre klinische Bedeutung. Münch. med. Wschr. 1952, 94, 2313.

19. Jencks, W. P., Smith, E. R. B., and Durrum, E. L. The clinical significance of the analysis of serum protein distribution by filter paper electrophoresis. Amer. J. Med. 1956, 21, 387.

20. Pieper, J. Uber die besonderen Eiweissfraktion des. Liquor cerebrospinalis. Klin. Wschr. 1954, 32, 597.

21. Gavrilesco, K., Courcon, J., Hillion, P., Uriel, J., Lewin, J., and Grabar, P. A study of normal human cerebrospinal fluid by the immuno-electrophoretic method. Nature (Lond.) 1956, 176, 976.

22. Schultze, H. E., Schönenberger, M., and Schwick, G. Utber ein Prëalbumin des menschlichen Serums. Biochem. Z. 1956, 328, 267.

23. Steger, J. Elektrophoretische Untersuchungen des Liquors. Dtsch. Z. Nervenheik. 1953, 171, 1.

24. Bauer, H. Zur frage der Identität der Liquorproteine mit den Eiweisskörpern des Blutserums. I. Besonderheiten des Liquorproteine hinsichtlich der Vorfraktion, der $\gamma$-Globuline und der proteingebundenen Lipide. Dtsch. Z. Nervenheik. 1956, 175, 354.

25. Bauer, $\mathrm{H}$. Uber die Bedentung der Papier-Elektrophorese des Liquors für die klinische Forschung. Dtsch. Z. Nervenheik. 1953, 170, 381.

26. Robertson, D. M. The electrophoretic separation of the soluble proteins of the brain. J. Neurochem. $1957,1,358$. 